\title{
Penanaman Konsep Berhitung Anak melalui Permainan Pencocokkan Kepingan Buah
}

\author{
Eva Delfia ${ }^{\otimes_{1}}$,Farida Mayar ${ }^{2}$ \\ Pendidikan Anak Usia Dini, Universitas Negeri Padang \\ DOI: $\underline{10.31004 / o b s e s i . v 4 i 1.350}$
}

\begin{abstract}
Abstrak
Penelitian ini bertujuan untuk mendeskripsikan bagaimana penerapan pelaksanaan permainan pencocokkan kepingan buah dalam menanamkan konsep berhitung kepada anak.Jenis penelitian yang digunakan yaitu deskriptif kualitatif.Adapun teknik pengumpulan data yang digunakan adalah observasi, wawancara dan dokumentasi.Aktivitas dalam analisis datameliputi data reduction, data display, dan conclusion drawing/ verification.Hasil yang diperoleh dalam penelitian ini mengenai penerapan permainan pencocokkan kepingan buah dalam menanamkan konsep berhitung anak dalam pembelajaran matematika anak usia dini. Membantu perkembangan kognitif anak dan mendorong pengembangan berbagai potensi intelektual seperti matematika yaitu kemampuan berhitung anak dalam mencocokkan, mengurutkan, membandingkan sehingga kemampuan berhitung berkembang secara optimal sesuai dengan tahap usia.
\end{abstract}

Kata Kunci : berhitung; permainan pencocokkan kepingan buah; taman kanak-kanak

\begin{abstract}
This study aims to describe how to apply the crab matching game in applying the concept of counting to children. This type of research is descriptive qualitative. The data collection techniques used are observation, interview and documentation. Activities in data analysis include data reduction, data display, and drawing conclusions / verification. The results obtained in this study about the application of fruit matching games in instilling the concept of counting children in early childhood mathematics learning. Helps cognitive development of children and encourages the development of intelligence potential such as mathematics about children's numeracy ability in matching, sorting, comparing with optimal developing numeracy abilities according to age.
\end{abstract}

Keywords: numeracy, fruit matching games, kindergarten

Copyright (c) 2019 Eva Delfia, Farida Mayar

$\triangle$ Corresponding author:

Email Address : evadelfiapaud2018@gmail.com (Punai Merindu, Keliling Danau, Kerinci, Jambi)

Received 27 November 2019, Accepted 5 December 2019, Published 7 December 2019

\section{PENDAHULUAN}

Secara intelektual kemampuan atau perkembangan anak itu berbeda-beda, baik itu intelegensi, kreativitas, kemandirian, sosial emosional, bahasa, kognitif, nilai agama dan moral, fisik motorik. Setiap anak itu memiliki perbedaan tersendiri serta memiliki kemampuan yang tak terbatas ini semua didapatkan oleh anak saat di jenjang pendidikan anak usia dini. Menurut (Isnaningsih \& Rohman, 2019) anak usia dini berada pada rentan 
usia 0-6 tahun. (Inten \& Permatasari, 2019) Anak usia dini merupakan individu yang sedang mengalami proses perkembangan yang fundamental bagi kehidupannya kelak. Pada tahapan usia dini, anak akan mengalami perkembangan dan pertumbuhan fisik serta mental yang cukup banyak. Pada usia ini pula anak akan merespon serta mengolah berbagai hal yang diterimanya dengan cepat.

Menurut (Undang-undang Sistem Pendidikan Nasional Nomor 20 Tahun 2003, n.d.) Bab I pasal 1 Nomor 14 yang menyatakan "Pendidikan Anak Usia Dini adalah suatu upaya pembinaan yang ditujukan kepada anak sejak lahir sampai dengan enam tahun yang dilakukan melalui pemberian rangsangan pendidikan untuk membantu pertumbuhan dan perkembangan jasmani dan rohani agar anak memiliki kesiapan dalam memasuki pendidikan lebih lanjut". Pendidikan Taman Kanak-kanak mengupayakan program pengembangan prilaku atau pembiasaan dan kemampuan dasar pada diri anak secara optimal. Dalam rangka mengoptimalkan perkembangan anak melalui pendidikan anak usia dini, program pendidikan harus disesuaikan dengan karakteristik anak yang mempunyai pengalaman dan pengetahuan yang berbeda. Program pendidikan harus memberikan rangsangan-rangsangan, dorongan dan dukungan kepada anak. Program pendidikan untuk anak, harus memperhatikan seluruh aspek perkembangan anak serta disesuaikan dengan kebutuhan, minat dan kemampuan anak (Suprapti, 2016).

(Waspodo, 2012) Pendidikan anak usia dini adalah usaha sadar dalam memfasilitasi pertumbuhan dan perkembangan jasmani dan rohani anak sejak lahir sampai dengan usia enam tahun yang dilakukan melalui penyediaan pengalaman dan stimulasi yang kaya dan bersifat mengembangkan secara terpadu dan menyeluruh agar anak dapat tumbuh dan kembang secara sehat dan optimal sesuai dengan nilai, norma, dan harapan masyarakat.

(Mursid, 2015) menyatakan bahwa pendidikan anak usia dini adalah Salah satu bentuk penyelenggaraan pendidikan yang menitikberatkan pada peletakan dasar ke arah pertumbuhan dan perkembangan fisik (koordinasi motorik halus dan kasar), kecerdasan (daya pikir, daya cipta, kecerdasan emosi, kecerdasar spiritual), sosial emosional (sikap dan perilaku serta beragama), bahasa dan komunikasi, sesuai dengan keunikan dan tahap-tahap perkembangan yang dilalui oleh anak usia dini.

(Fakhruddin, 2010) pendidikan anak usia dini adalah Suatu upaya pembinaan yang ditujukan kepada anak sejak lahir sampai dengan usia enam tahun yang dilakukan melalui pemeberian rangsangan pendidikan untuk membantu pertumbuhan dan perkembangan jasmani dan rohani agar anak memiliki kesiapan dalam memasuki pendidikan lebih lanjut.

Pendidikan anak usia dini khususnya di Taman Kanak-kanak sangat penting sekali serta merupakan salah satu jenjang pendidikan yang harus diperhatikan. Taman Kanakkanak merupakan salah satu bentuk pendidikan anak usia dini pada jalur formal yang menyediakan program pendidikan anak umur 0 sampai 6 tahun yang bertujuan untuk membantu mengembangkan potensi yang dimiliki oleh anak, baik psikis dan fisik yang meliputi nilai-nilai moral, agama, disiplin, sosial emosional, kemandirian, kognitif, bahasa, fisik, motorik, dan seni untuk setiap memasuki pendidikan selanjutnya.

(Suryana, 2013) menyatakan anak usia dini adalah sosok individu sebagai makhluk sosiokultural yang sedang mengalami proses perkembangan yang sangat fundemental bagi kehidupan selanjutnya dan memiliki sejumlah karakteristik tertentu. Usia dini merupakan usia yang sangat penting bagi perkembangan anak sehingga di sebut golden age. Masa ini merupakan masa pembentukan jaringan otak dan pertumbuhan psikis dan emosional anak, hal tersebut agar pertumbuhan dan perkembangan anak itu baik dan berjalan sesuai dengan kematangan usianya, jangan sampai masa emas ini berlalu tanpa adanya rangsangan dan stimulus yang sesuai dengan tahap perkembangan dan pertumbuhan anak salah satunya kemampuan yang harus dikembangkan adalah kemampuan berhitung anak dalam pembelajaran matematika anak usia dini. Karena berhitung adalah bagian dari matematika. 
Menurut (Mirawati, 2017) Pembelajaran matematika untuk anak merupakan sarana yang dapat digunakan untuk mengembangkan kemampuan berpikir, mendorong anak untuk mengembangkan berbagai potensi intelektual yang dimilikinya serta data dijadikan sebagai sarana untuk menumbuhkan berbagai sikap dan perilaku positif dalam rangka meletakkan dasar kepribadian sedini mungkin seperti sikap kritis, ulet, mandiri, ilmiah, dan rasional. (Ismayani, 2010) matematika adalah sesuatu sistem abstrak untuk pengalaman dalam mengorganisasikan serta mengurutkan dengan cara berhitung. Anak usia Taman Kanak-kanak berpikir secara konkret, konsep atau urutan tidak akan berarti apa-apa bagi mereka kecuali mereka memiliki sesuatu konkret untuk bisa dihitung dan diurutkan.

Tujuan pembelajaran matematika berdasarkan pendapat (Sujiono, 2009) permainan matematika bertujuan agar anak dapat mengetahui dasar-dasar pembelajaran berhitung dalam suasana yang menarik, aman, nyaman, dan menyenangkan, sehingga diharapkan nantinya anak akan memiliki kesiapan dalam mengikuti pembelajaran matematika yang sesungguhnya disekolah dasar.

Dalam kehidupan sehari-hari manusia tidak pernah lepas dari matematika. Sebagai pemecahan masalah dari makna ataupun lambang, pembelajaran matematika untuk anak merupakan sarana yang dapat digunakan untuk mengembangkan kemampuan berpikir, mendorong anak untuk mengembangkan berbagai potensi intelektual yang dimilikinya serta data dijadikan sebagai sarana untuk menumbuhkan berbagai sikap dan perilaku positif. Dalam pembelajaran matematika perlu ditanamkan konsep berhitung pada anak. Sebelum anak diajarkan untuk berhitung, terlebih dahulu anak harus bisa menghitung dan mengetahui angka-angka dalam menghitung tersebut, baik itu urutannya maupun arti dari setiap angka tersebut (Amaris, Rakimahwati, \& Marlina, 2018).

Kemampuan berhitung merupakan kemampuan dalam mengunakan penalaran, logika dan angka-angka. Berhitung merupakan bagian dari matematika diperlukan untuk menumbuh kembangakan keterampilan berhitung yang sangat di perlukan dalam kehidupan sehari-hari terutama konsep bilangan yang merupakan dasar bagi pengembangan kemampuan matematis.

Kegiatan pembelajaran matematika untuk kemampuan berhitung anak di Taman Kanak-kanak dapat dilakukan dengan berbagai kegiatan, salah satunya melalui bermain. Bermain dapat mengembangkan kemampuan berfikir anak serta mengembangkan kemampuan berhitung anak dengan memberikan rangsangan yang baik kepada anak yaitu bisa kita lakukan dengan menggunakan jenis alat permainan yang menarik bagi anak.

Menurut (Pradana, 2016) pembelajaran melalui bermain dapat memperoleh pemenuhan rasa ingin tahunya dan anak mendapat banyak latihan dalam mengamati sendiri, membandingkan, sehingga anak dapat menemukan cara dalam menyelesaikan atau memecahkan masalah yang di hadapi. Bermain merupakan pendekatan dalam melaksanakan pembelajaran pada anak usia dini. Kegiatan pembelajaran yang disiapkan oleh guru hendaknya dilakukan dalam situasi yang menyenangkan dengan menggunakan strategi, metode, materi dan media yang menarik. (Dewi, Hapidin, \& Akbar, 2019) Proses pembelajaran tidak pernah luput dari berbagai macam metode, teknik, strategi, media, dan model pembelajaran yang variatif sesuai dengan tujuan dan kebutuhan.

Menurut Duque dkk dalam (Perdina, Safrina, \& Sumadi, 2019) menyatakan bahwa bermain merupakan kegiatan yang penting bagi anak karena dalam kegiatan bermain anak dapat bereksperimen melalui perasaan, sentuhan, ucapan, dan interaksi sosial dengan orang lain.

Melalui bermain anak dapat bereksplorasi, menemukan dan memanfaatkan objek yang dekat dengan anak, sehingga pembelajaran menjadi bermakna. Salah satu permainan yang dapat kita gunakan untuk menanamkan konsep berhitung anak adalah permainan pencocokkan kepingan buah dalam menanamkan konsep berhitung anak. Permianan pencocokkan kepingan buah menurut (Ismayani, 2010) adalah suatu permainan yang dimainkan anak dengan cara anak membandingkan untuk mengetahui cocok atau tidaknya 
sesuatu. Dengan konsep berhitung yang telah di miliki, anak akan mampu mengembangkan konsep mencocokkan kepingan buah yang terdapat angka dan gambar.

Melalui permainan ini dapat membantu anak dalam mengembangkan kemampuan berhitungnya, karena permainan pencocokkan kepingan buah ini anak terlibat langsung dalam kegiatan yang mana anak mengambil kepingan buah yang terdapat gambar buah kemudian anak mencocokkan jumlah gambar yang terdapat pada kepingan buah tersebut dengan cara anak menghitung gambarnya kemudian anak mencocokkan dengan angka sesuai dengan jumlah gambar yang telah dihitung anak, kemudian setelah anak menemukan dan mencocokkan terbentuk lah buah yang utuh.

Menurut (Smith, 2009) berhitung yang dapat dilakukan dengan menggunakan penghitungan lisan dengan cara berpikir yaitu membaca angka, mencocokkan nomor ke satu set, memiliki nuansa intuitif untuk seberapa besar angka, membuat tebakan yang masuk akal menggunakan angka, dan melihat hubungan sebagian-bagian dengan karateristik tersendiri sesuai dengan tahapan usianya. Masa usia dini (0-6 tahun) masa keemasan (golden age) dimana stimulasi seluruh aspek perkembangan berperan penting untuk tugas perkembangan selanjutnya.

Konsep korespondensi satu-satu dan mencocokkan juga konsep dasar dari berhitung. Berhitung mencangkup kemampuan untuk menggunakan angka dan perhitungan pola, logika dan pola pikir ilmiah, secara umum permainan berhitung mengetahui dasar berhitung anak sejak usia menggunakan penglihatan atau pemikiran abstrak.

Mengingat kemampuan berhitung bagi anak itu sangat penting dikembangkan maka dari itu guru di tuntut untuk menciptakan suatu kegiatan pembelajaran yang menarik dan pembelajaran yang kreatif untuk anak dalam membantu mengembangkan kemampuan berhitung anak dengan menggunakan berbagai macam metode pembelajaran salah satunya bisa dilakukan melalui bermain. Penelitian ini bertujuan untuk mendeskripsikan bagaimana penerapan pelaksanaan permainan pencocokkan kepingan buah dalam menanamkan konsep berhitung kepada anak.

\section{METODOLOGI}

Jenis penelitian ini menggunakan deskriptif kualitatif. Metode ini dipilih karena penelitian ini mengkaji secara terinci dan mendalam tentang aktivitas pembelajaran penanaman konsep berhitung anak melalui permainan pencocokkan kepingan buah di Taman Kanak-kanak PGRI Kerinci yang kemudian mendeskripsikan data tersebut secara sinergis sesuai kenyataan atau pengamatan dilapangan, serta tetap berkesinambungan berdasarkan proses penelitian yang peneliti lakukan di Taman Kanak-kanak PGRI Kerinci tersebut. Subjek yang digunakan dalam penelitian ini adalah diarahkan kepada pihak-pihak yang terkait dan kompeten dalam proses penyelenggaraan pendidikan di Taman Kanakkanak PGRI Kerinci. Sumber data peneliti adalah guru kelas B1 dan kepala sekolah di Taman Kanak-kanak PGRI. Adapun Teknik pengumpulan data yang digunakan adalah observasi yang dilakukan secara terstruktur, wawancara semi terstruktur dengan menggunakan schedule questioner atau interview guide, dan dokumentasi berbentuk gambar berupa foto kegiatan pembelajaran penanaman konsep berhitung anak melalui permainan pencocokkan buah di taman kanak-kanak PGRI Kerinci. Dalam menganalisis data, peneliti menggunakan model Miles dan Huberman selama berada di lapangan. Aktivitas dalam analisis datameliputi data reduction, data display, danconclusion drawing/verification.

\section{HASIL DAN PEMBAHASAN}

Penelitian ini dilakukan pada hari Rabu tanggal 16 Oktober 2019, biasanya guru-guru di Taman Kanak-kanak PGRI Kerinci mengintegrasikan berbagai pembelajaran salah satunya dalam penanaman konsep berhitung untuk anak usia dini. pengembangan konsep 
berhitung anak dilakukan melalui kegiatan yaitu melalui suatu permainan dengan menggunakan permainan pencocokkan kepingan buah dalam mengembangkan kemampuan berhitung anak.

\section{Perencanaan Pembelajaran Penanaman Konsep Berhitung}

Perencanaan pembelajaran adalah langkah dasar yang harus dilakukan oleh guru sebelum melaksanakan pembelajaran, dalam membuat suatu perencanaan pembelajaran terlebih dahulu guru membuat Rencana Pelaksanaan Pembelajaran Mingguan (RPPM) selain itu guru mengembangkan nya dalam bentuk Rencana Pelaksanaan Pembelajaran Harian $(\mathrm{RPPH})$. Sehingga RPPM dan RPPH tersebut dapat dijadikan acuan atau pedoman guru untuk melaksanakan pembelajaran. Berdasarkan hasil observasi dan wawancara yang dilakukan pada tanggal 16 November 2019 tepatnya hari rabu di Taman Kanak-kanak PGRI Kerinci terlihat bahwa di sekolah tersebut dalam merancang pembelajaran yang disusun oleh guru sudah berdasarkan kurikulum 2013 baik itu dalam membuat program semester I maupun program semester II terlebih dahulu untuk mengelompokkan tema, subtema berdasarkan program semester yang dirancang oleh guru pada setiap awal tahun ajaran baru.

Setelah membuat program semester guru membuat Rencana Pelaksanaan Pembelajaran Mingguan (RPPM) berdasarkan program semester yang dibuat oleh guru pada tahun ajaran baru. Dari RPPM tersebut guru membuat RPPH untuk dijadikan pedoman mengajar setiap harinya, selain itu guru juga merancang media yang menarik untuk anak. Dalam RPPH tersebut berisi Tema/Sub Tema, Sub-sub Tema, Kopetensi Dasar, Indikator, pijakan lingkungan bermain, pijakan sebelum bermain, pijakan setelah bermain, istirahat, kegiatan penutup.

Berdasarkan observasi dan wawancara peneliti menemukan bahwa dalam perencanaan pembelajaran yang dibuat oleh guru baik itu berupa program semester, RPPM, RPPH terlihat bahwa sudah sesuai dengan ketentuan dan prosedur yang telah ditentukan. Tema yang digunakan ketika peneliti observasi dan wawancara di Taman Kanak-kanak PGRI kerinci tersebut adalah tema tanaman dengan sub tema buah-buahan dan sentra yang digunakan adalah sentra persiapan.

\section{Pelaksanaan Pembelajaran Penanaman Konsep Berhitung Anak Melalui Permainan Pencocokkan Kepingan Buah}

Pelaksanaan pembelajaran dilaksanakan berdasarkan RPPH yang telah dibuat oleh guru yang meliputi pembukaan yaitu guru memperkenalkan tema, sub tema, yang digunakan pada hari tersebut, serta guru memperkenalkan apa kegiatan permainan dan langkah-langkah kegiatan permainan yang akan dilakukan oleh anak, kegiatan inti yang dilakuakan oleh anak sesuai dengan materi dan tujuan pembelajaran dan langkah-langkah permainan yang telah diberikan atau yang telah dibuat oleh guru, istirahat, kegiatan penutup dilakukan dengan metode bercakap-cakap, tanya jawab yaitu guru menanyakan kembali kepada anak bagaimana perasaan anak setelah melakukan kegiatan dan apa kegiatan yang dilakukan oleh anak tersebut pada kegiatan inti.

Berdasarkan observasi dan wawancara yang telah dilakukan peneliti bahwa pelaksanaan pembelajaran penanaman konsep berhitung anak melalui permainan pencocokkan kepingan buah di Taman Kanak-kanak PGRI Kerinci metode yang digunakan oleh guru sangat bervariasi yaitu metode bercakap-cakap, metode tanya jawab, metode pemberian tugas. Metode bercakap-cakap yang digunakan oleh guru ketika guru menjelaskan kepada anak mengenai tanaman, bagaimana bentuk tanaman, macam-macam tanaman, serta guru memperkenalkan kepada anak macam-macam buah-buahan, warna buah-buahan. Metode tanya jawab yang digunakan oleh guru ketika guru menanyakan kepada anak siapa yang pernah makan buah-buahan, bagaimana rasa buah-buahan. kemudian metode pemberian tugas yaitu anak melakukan suatu permainan yang telah di 
buat oleh guru dengan menggunakan media kepingan buah yang berbentuk berbagai macam buah yang dibuat oleh guru dari kain planel dan pada kepingan buah tersebut terdapat angka berdasarkan jumlah gambar buah yang ada pada kepingan buah.

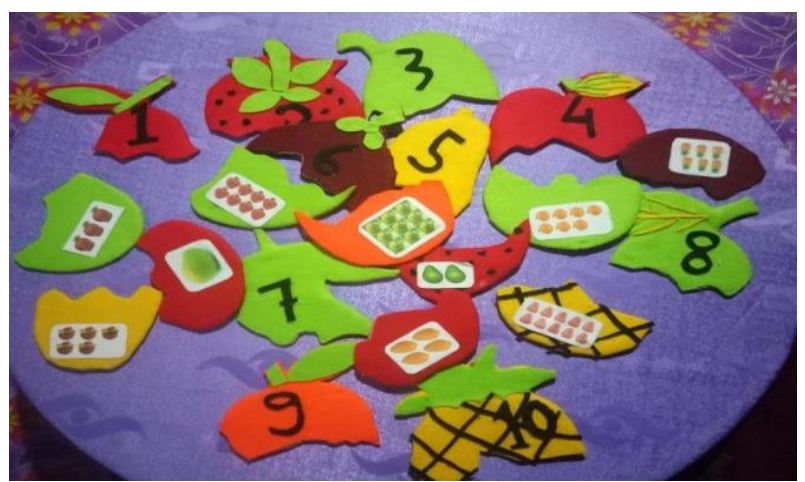

Gambar 1. Media Permainan Pencocokkan Kepingan Buah

Guru menjelaskan apa saja nama buah-buahan yang terdapat pada kepingan buah serta guru memperlihatkan kepada anak media permainan pencocokkan kepingan buah secara acak yaitu terdapat angka 1-10 dengan berbagai macam bentuk buah-buahan.

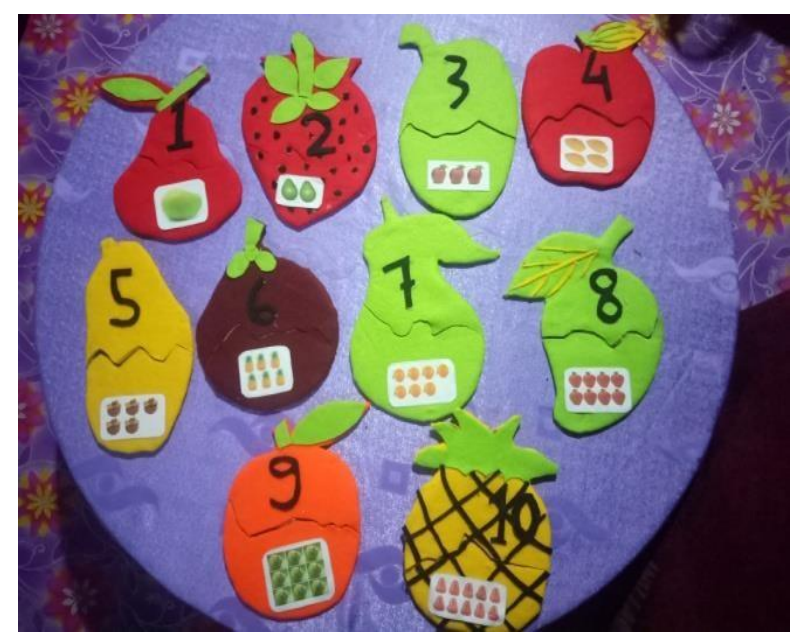

Gambar 2. Media Permainan yang Telah Dicocokkan oleh Guru Berdasarkan Jumlah Gambar

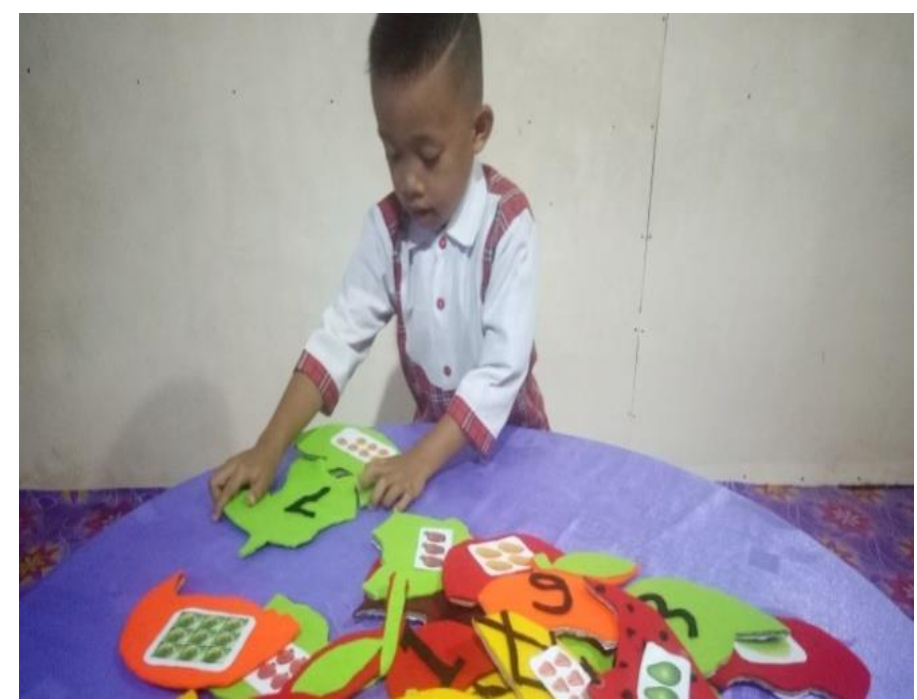

Gambar 3. Anak Mengambil Kepingan Buah yang Terdapat Gambar dan Mencari Lawan Kepingan Buah Berdasarkan Jumlah Gambar Buah 
Anak terlebih dahulu mengetahui bentuk buah dan bilangan karena apabila anak sudah mengetahui hal tersebut maka anak akan merasa mudah dalam mencari kepingan buah atau mencarikan pasangan kepingan buah tersebut.

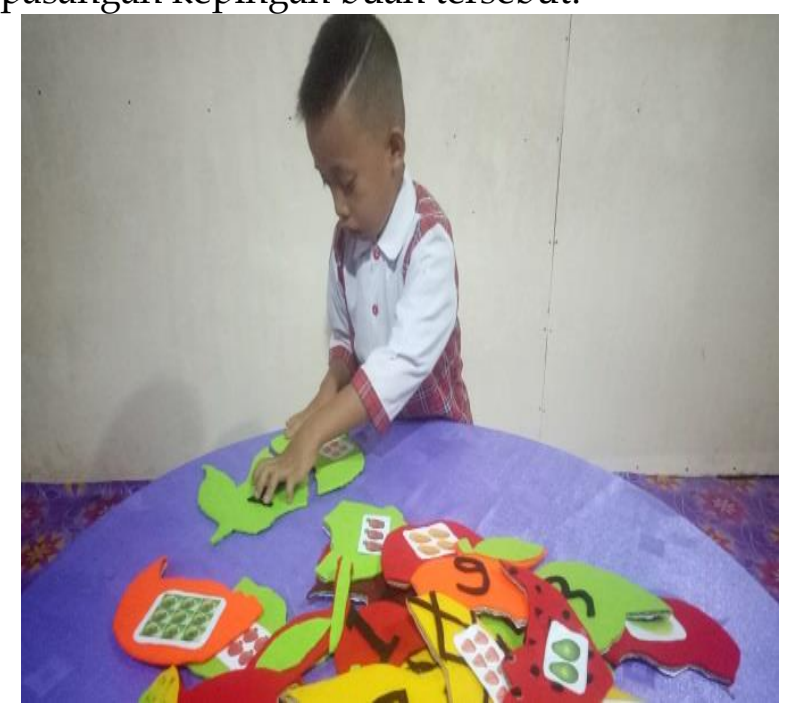

Gambar 4. Menghitung Jumlah Gambar Buah yang Terdapat Pada Kepingan Buah

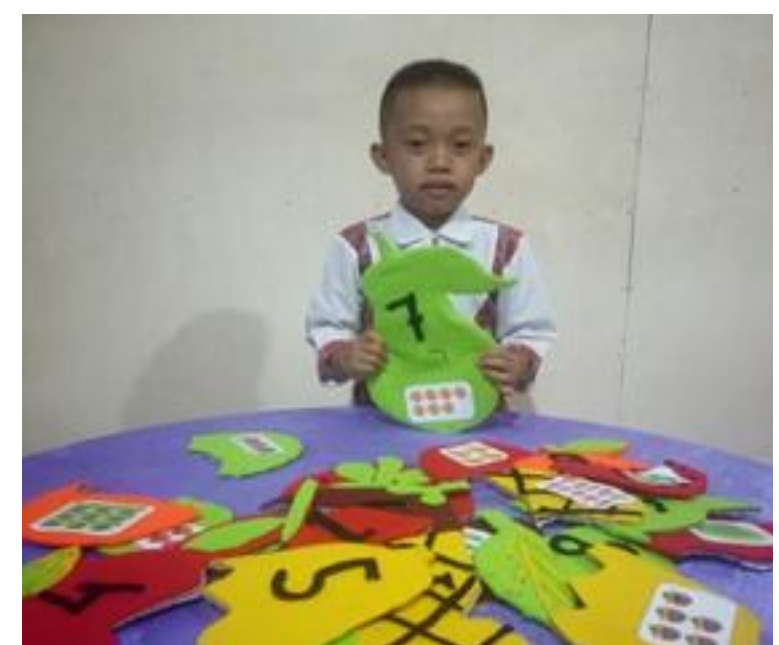

Gambar 5. Anak Mencocokkan Kepingan Buah yaitu Kepingan Buah Alpokat yang Terdapat Tujuh Gambar Dengan Mencari Angka 7 Berdasarkan Jumlah Gambar yang Telah Dihitung

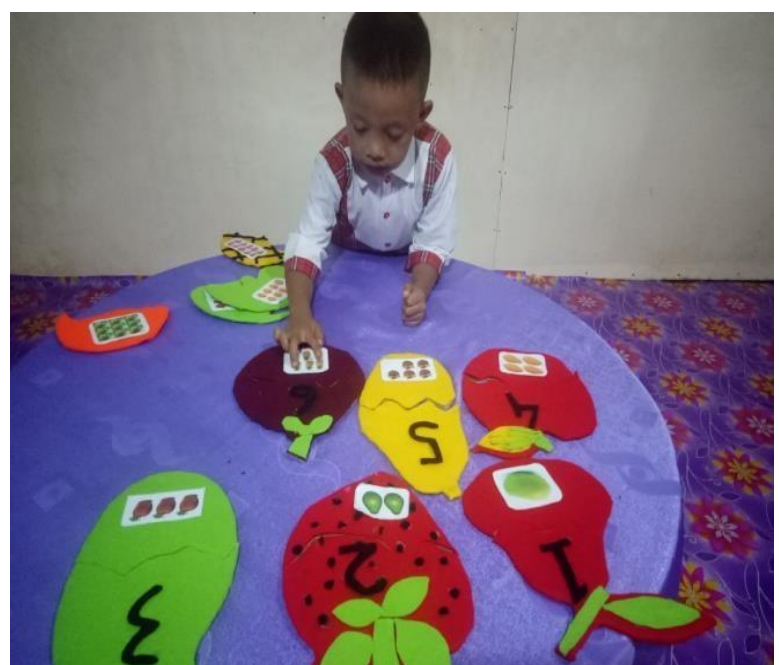

Gambar 6. Anak Mencocokkan Semua Kepingan Buah Dengan Cara Anak Mencocokkan DenganAngka yang Dimulai Dari Angka1-10 


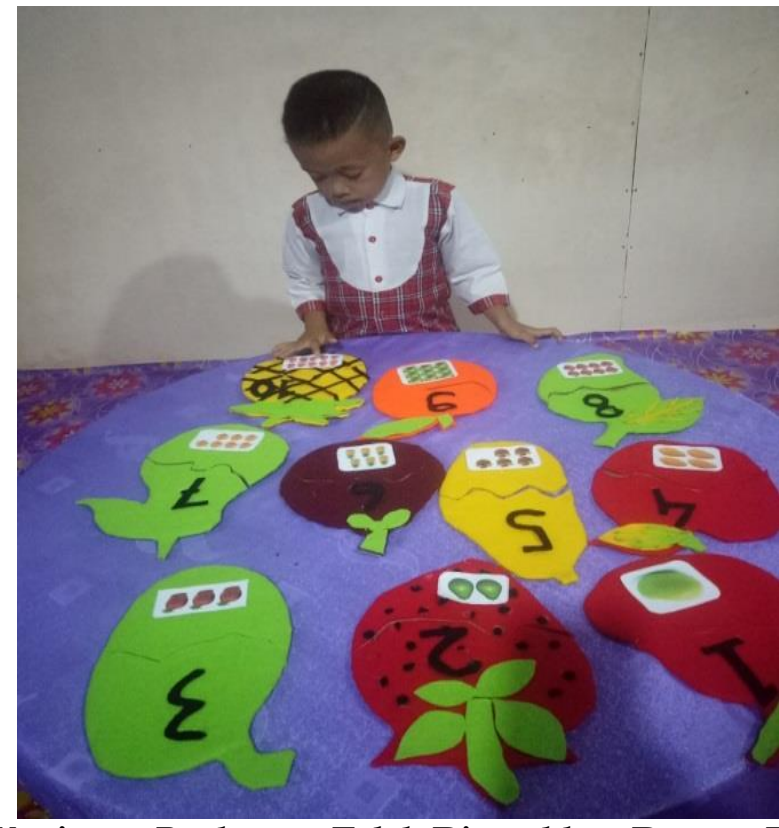

Gambar 7. Kepingan Buah yang Telah Dicocokkan Dengan Berhitung

\section{Evaluasi Penanaman Konsep Berhitung}

Penilaian yang dilakukan oleh guru ketika anak bermain kepingan buah yaitu bagaimana proses yang dilakukan oleh anak dalam menyelesaikan suatu permainan dalam mengembangkan kemampuan berhitung anak. Penilaian ini sangat penting dilakukan oleh guru sehingga agar dapat mengetahui bagaimana perkembangan anak setiap harinya dengan kegiatan yang telah guru berikan kepada anak.

Berdasarkan Observasi dan wawancara yang telah dilakukan oleh peneliti dalam pelaksanaan penanaman konsep berhitung anak melalui permainan pencocokkan kepingan buah di Taman Kanak-kanak PGRI Kerinci. Guru melakukan evaluasi untuk melihat sejauh mana perkembangan konsep berhitung dan perkembangan berhitung anak. Evaluasi yang dilakukan oleh guru disaat kegiatan pembelajaran berlangsung yaitu dari proses yang dilakukan oleh anak ketika anak bermain kepingan buah yaitu ketika anak mengambil kepingan buah yang terdapat gambar dan mencari lawan kepingan buah berdasarkan jumlah gambar buah, ketika anak menghitung jumlah gambar buah yang terdapat pada kepingan buah, anak mencocokkan kepingan buah yaitu kepingan buah alpokat yang terdapat tujuh gambar dengan mencari angka 7 berdasarkan jumlah gambar yang telah dihitung, anak mencocokkan semua kepingan buah dengan cara anak mencocokkan denganangka yang dimulai dari angka1-10.

Ketika anak melakukan kegiatan permainan pencocokkan kepingan buah ini guru tetap mendampingi anak ketika anak melakukan permainan dari awal sampai akhir, dengan adanya keikutsertaan guru maka guru dapat mengevaluasi dan melihat langsung bagaimana kemampuan anak dalam berhitung, kemampuan anak dalam mencocokkan gambar dengan angka melalui media pembelajaran yang diberikan oleh guru yaitu melalui perimanan pencocokkan kepingan buah tersebut.

Selain itu Evaluasi yang dilakukan oleh guru yaitu dengan unjuk kerja anak ketika kegiatan berlangsung yaitu guru menilai berapa anak yang mengikuti kegiatan permainan pencocokkan kepingan buah dan berapa anak yang tidak mengikutinya, berapa anak yang dapat melakukan kegitan sendiri dan masih dibantu teman, maupun gurunya. Penilaian yang dilakukan oleh guru yaitu juga menggunakan catatan anekdot dan daftar chek list yaitu guru melihat atau mengamati anak setiap harinya tentang perkembangan anak mulai anak datang kesekolah sampai anak pulang sekolah. Sehingga guru mengetahui bagaimana perkembangan masing-masing anak. 
Tabel 1. Hasil Observasi Penanaman Konsep Berhitung Anak di Taman Kanak-kanak PGRI Kerinci

\begin{tabular}{|c|c|c|}
\hline No & Diamati & Deskripsi \\
\hline 1 & $\begin{array}{l}\text { Perencanaan pembeajaran } \\
\text { penanaman konsep } \\
\text { berhitung }\end{array}$ & $\begin{array}{l}\text { Perencanaan pembelajaran penanaman konsep berhitung } \\
\text { dibuat oleh guru berdasarkan kurikulum yang ada dibuat } \\
\text { dalam bentuk RPPH yang berisi tentang tema, sub tema, sub- } \\
\text { sub tema, materi, tujuan pembelajaran }\end{array}$ \\
\hline \multirow[t]{4}{*}{2} & $\begin{array}{l}\text { Pelaksanaan pembelajarn } \\
\text { penanaman konsep } \\
\text { berhitung anak melalui } \\
\text { permainan pencocokkan } \\
\text { kepingan buah }\end{array}$ & $\begin{array}{l}\text { Pelaksanaan pembelajaran penanaman konsep berhitung } \\
\text { dilaksanakan sesuai dengan RPPH yang dirancang oleh guru } \\
\text { sebagai acuan dalam proses pelaksanaan pembelajaran }\end{array}$ \\
\hline & $\begin{array}{l}\text { a)Guru mempersiapkan } \\
\text { perlengkapan untuk } \\
\text { pembelajaran penanaman } \\
\text { konsep berhitung }\end{array}$ & $\begin{array}{l}\text { Perlengkapan yang dibutuhkan dalam penanaman konsep } \\
\text { berhitung anak di sediakan atau diletakkan oleh guru terlebih } \\
\text { dahulu sebelum kegiatan pembelajaran dimulai }\end{array}$ \\
\hline & $\begin{array}{l}\text { b.)Metode yang digunakan } \\
\text { dalam penanaman konsep } \\
\text { berhitung }\end{array}$ & $\begin{array}{l}\text { Untuk penanaman konsep berhitung anak melalui permainan } \\
\text { pencocokkan kepingan buah ini dilakukan oleh guru } \\
\text { melalui metode bercakap-cakap, metode tanya jawab, dan } \\
\text { metode pemberian tugas. }\end{array}$ \\
\hline & $\begin{array}{l}\text { c. Media yang digunakan } \\
\text { guru dalam penanaman } \\
\text { konsep berhitung }\end{array}$ & $\begin{array}{l}\text { Dalam penanaman konsep berhitung anak guru menggunakan } \\
\text { media pencocokan kepingan buah yang dilakukan oleh anak } \\
\text { dengan cara anak bermain }\end{array}$ \\
\hline 3 & $\begin{array}{l}\text { Evaluasi penanaman } \\
\text { konsep berhitung anak } \\
\text { melalui permainan } \\
\text { pencocokkan kepingan } \\
\text { buah }\end{array}$ & $\begin{array}{l}\text { Disaat kegiatan penanaman konsep berhitung anak } \\
\text { berlangsung evaluasi yang dilakukan oleh guru yaitu melalui } \\
\text { proses dan hasil, guru mengevaluasi bagaimana proses di saat } \\
\text { anak menghitung jumlah gambar buah yang terdapat pada } \\
\text { kepingan buah, anak mencocokkan kepingan buah angka yang } \\
\text { dimulai dari angka1-10. }\end{array}$ \\
\hline
\end{tabular}

Tabel 2. Hasil Wawancara Dengan Kepala Sekolah dan Guru di Taman Kanak-kanak PGRI Kerinci tentang Penanaman Konsep Berhitung Anak

\begin{tabular}{|c|c|c|}
\hline $\begin{array}{c}\text { Aspek yang di } \\
\text { Wawancara }\end{array}$ & Pertanyaan & Simpulan Jawaban Informan \\
\hline $\begin{array}{l}\text { Perencanaan } \\
\text { Pembelajaran } \\
\text { Penanaman Konsep } \\
\text { Berhitung }\end{array}$ & $\begin{array}{l}\text { Bagaimana bentuk } \\
\text { perencanaan pembelajaran } \\
\text { yang dirancang oleh ibuk } \\
\text { dalam menanamkan konsep } \\
\text { berhitung anak melalui } \\
\text { permainan pencocokkan } \\
\text { kepingan buah? }\end{array}$ & $\begin{array}{l}\text { Menyesuaikan dengan kurikulum yang } \\
\text { yang ada dibuat dalam bentuk RPPH } \\
\text { dan sesuai dengan tahap } \\
\text { perkembangan anak }\end{array}$ \\
\hline $\begin{array}{l}\text { Pelaksanaan } \\
\text { Pembelajaran } \\
\text { Penanaman Konsep } \\
\text { Berhitung Anak } \\
\text { Melalui Permainan } \\
\text { Pencocokkan } \\
\text { Kepingan Buah }\end{array}$ & $\begin{array}{l}\text { Bagaimana bentuk } \\
\text { pelaksanaan pembelajaran } \\
\text { penanaman konsep } \\
\text { berhitung melalui } \\
\text { permainan pencocokkan } \\
\text { kepingan buah? } \\
\text { Apa saja metode yang ibuk } \\
\text { gunakan dan bagaimana } \\
\text { penerapan metode tersebut } \\
\text { dalam menanamkan } \\
\text { konsep berhitung anak? }\end{array}$ & $\begin{array}{l}\text { Bentuk Pelaksanaan pembelajaran } \\
\text { penanaman konsep berhitung } \\
\text { dilaksanakan sesuai dengan RPPH yang } \\
\text { dibuat oleh guru sebagai acuan untuk } \\
\text { melaksanakan pembelajaran yang berisi } \\
\text { tentang kegiatan pembuka, kegiatan } \\
\text { inti, istirahat, dan kegiatan penutup } \\
\text { Metode yang digunakan guru adalah } \\
\text { metode bercakap-cakap yang dilakukan } \\
\text { oleh guru kepada anak untuk } \\
\text { memperkenalkan tema, sub tema, } \\
\text { menjelaskan kegiatan penanaman } \\
\text { konsep berhitung., metode tanya jawab } \\
\text { yang dilakukan guru yaitu guru }\end{array}$ \\
\hline
\end{tabular}




\begin{tabular}{|c|c|c|}
\hline $\begin{array}{c}\text { Aspek yang di } \\
\text { Wawancara }\end{array}$ & Pertanyaan & Simpulan Jawaban Informan \\
\hline $\begin{array}{l}\text { Evaluasi } \\
\text { Penanaman Konsep } \\
\text { Berhitung anak } \\
\text { Melalui Permainan } \\
\text { Pencocokkan } \\
\text { Kepingan Buah }\end{array}$ & $\begin{array}{l}\text { Bagaimana cara } \\
\text { penggunaaan media } \\
\text { kepingan buah yang ibuk } \\
\text { gunakan dalam } \\
\text { pelaksanaan pembelajaran } \\
\text { penanaman konsep } \\
\text { berhitung anak? } \\
\text { Bagaimana car dan seperti } \\
\text { apa bentuk evaluasi yang } \\
\text { ibuk lakukan dalam } \\
\text { pelaksanaan pembelajaran } \\
\text { penanaman konsep } \\
\text { berhitung anak melalui } \\
\text { permainan pencocokkan } \\
\text { kepingan buah? }\end{array}$ & $\begin{array}{l}\text { menanyakan kepada anak tentang yang } \\
\text { berkaitan dengan kegiatan seperti } \\
\text { tanaman dan macam-macam buah- } \\
\text { buahan, metode pemberian tugas yaitu } \\
\text { anak menghitung jumlah kepingan } \\
\text { buah dan mencocokkan kepingan buah } \\
\text { berdasarkan jumlah gambar buah } \\
\text { dengan angka. Berdasarkan metode } \\
\text { tersebut guru bertanya kepada anak } \\
\text { berapa jumlah gambar buah-buahan } \\
\text { yang didapatkan oleh anak dan angka } \\
\text { berapa yang terdapat pada kepingan } \\
\text { buah. } \\
\text { Media kepingan buah tersebut } \\
\text { digunakan dengan cara seperti mencari } \\
\text { lawan kepingan buah dengan cara } \\
\text { menghitung jumlah gambar dan } \\
\text { mencocokkan jumlah gambar dengan } \\
\text { angka, serta mengurutkan kepingan } \\
\text { buah dari 1-10 } \\
\text { cara yang dilakukan untuk } \\
\text { mengevaluasi penanaman konsep } \\
\text { berhitung anak melalui permainan } \\
\text { pencocokkan kepingan buah ini yaitu } \\
\text { ketika proses kegiatan pembelajaran } \\
\text { berlangsung dan juga mengevaluasi } \\
\text { dari hasil }\end{array}$ \\
\hline
\end{tabular}

Berdasarkan hasil observasi dan hasil wawancara yang dibuat dalam bentuk tabel diatas bahwasanya kegiatan pembelajaran penanaman konsep berhitung anak di Taman Kanak-kanak PGRI kerinci termasuk kategori baik. Ini terlihat bahwa baik dari pembuatan perencanaan pembelajaran penanaman konsep berhitung, pelaksanaan pembelajaran penanaman konsep berhitung anak melalui permainan pencocokkan kepingan buah dengan menggunakan media yang sangat menarik bagi anak, baik dari segi warnanya, bentuk, dan ukuran nya, sehingga dengan anak nya media tersebut anak merasa senang dan antusias dalam mengikuti pembelajaran penanaman konsep berhitung. Karena untuk menanamkan konsep berhitung anak memang dibutuhkan media yang sesuai atau media nyata yang dapat dilihat langsung dan dimainkan langsung oleh anak untuk menghitung, mencocokkan, dan mengelompokkan.

Dalam pelaksanaan kegiatan pembelajaran tersebut guru menggunakan metode yang bervariasi dan tidak menonton sehingga pembelajaran yang disampaikan oleh guru dapat diterima baik oleh anak. Selain itu dalam pelaksanaan pembelajaran guru juga mengevaluasi bagaimana proses berjalannya kegiatan yang berlangsung dalam menanamkan konsep berhitung anak agar kemampuan berhitung anak berkembang dengan baik serta dari pengevaluasian tersebut guru dapat mengetahui sejauh mana kemampuan yang dimiliki oleh masing-masing anak.

Untuk mengetahui hasil kegiatan pembelajaran penanaman konsep berhitung di Taman Kanak-kanak PGRI Kerinci melalui permainan pencocokkan kepingan buah ini sangat cocok diterapkan untuk anak karena media yang digunakan sangat menarik sehingga pembelajaran yang disampaikan oleh guru dapat diterima anak dengan cepat. (Aprinawati, 2017) Media pembelajaran adalah segala sesuatu yang dapat menyalurkan pesan, 
merangsang pikiran, perasaan, dan kemauan anak sehingga mendorong terciptanya proses belajar pada diri anak.

Dengan adanya media yang menarik dapat mengembangkan kemampuan berhitung anak, karena pembelajaran berhitung itu sangat penting ditanamkan dalam diri anak. (Yanti, Turdjai, \& Kurniah, 2017) Mengatakan bahwa kemampuan berhitung perlu diajarkan sejak dini, dengan berbagai metode dan media yang tepat karena anak usia 5-6 tahun belum dapat melakukan kegiatan berhitung dengan sesungguhnya (berhitung bilangan abstrak). Pemahaman konsep berhitung kepada anak perlu diberikan sejak dini dengan menggunakan cara yang mudah dimengerti oleh anak (Reswita \& Wahyuni, 2018). Berhitung merupakan kegiatan untuk anak usia dini yang disebut juga sebagai kegiatan menyebutkan urutan bilangan (Malapata \& Wijayanigsih, 2019). Pemahaman konsep terhadap suatu bilangan merupakan hal yang penting dan mendasar khususnya bagi anak usia dini secara intelektual, anak masih belum mengerti tentang konsep bilangan. Namun mereka sudah memiliki pengertian tersebut secara intuitif dan perlahan dituntun menuju kepada suatu pemahaman intelektual secara simbolik (Hasiana \& Wirastania, 2017).

Sebelum anak diajarkan untuk berhitung, terlebih dahulu anak harus bisa menghitung dan mengetahui angka-angka dalam menghitung tersebut, baik itu urutannya maupun arti dari setiap angka tersebut (Amaris et al., 2018). Pengembangan aritmatika merupakan pengembangan kemampuan berhitung. Dalam kurikulum 2013 PAUD dijelaskan, bahwa anak harus mencapai beberapa poin penting dalam konsep berhitung, antara lain: menyebutkan lambang bilangan 1-10, menggunakan lambang bilangan untuk menghitung, dan mencocokan bilangan dengan lambang bilangan.

(Farihah, 2017) Berhitung merupakan salah satu kemampuan sangat penting bagi anak yang perlu dikembangkan dalam rangka membekali anak dikehidupannya dimasa depan. Berhitung merupakan dasar dari beberapa ilmu yang dipakai dalam setiap kehidupan manusia. Mengingat begitu pentingnya kemampuan berhitung bagi manusia, maka kemampuan berhitung ini perlu diajarkan sejak dini, dengan berbagai media, metode yang tepat sehingga tidak dapat merusak pola perkembangan anak. Menurut (Smith, 2009) pencocokkan dalam kemampuan berhitung misalnya pada konsep anak belajar untuk mengamati dan mengungkapkan lebih banyak atau lebih sedikit kegiatan mencocokan dapat dimulai dengan mencari perbedaan persamaan hingga konsep lebih banyak atau lebih sedikit.

Dapat dipahami bahwa permainan pencocokkan kepingan buah ini sebagai alat bantu berjalannya proses kegiatan pembelajaran dalam menanamkan konsep berhitung anak untuk merangsang dan menstimulus pikiran, perasaan, dan membatu anak menyelesaikan suatu masalah melalui kegiatan bermain.

\section{SIMPULAN}

Pada umunya setiap anak terlahir sebagai anak yang cerdas, kreatif. Namun, apabila diberikan stimulus dan treatment yang baik oleh seorang pendidik atau guru maka kemampuan berhitung anak akan lebih berkembang sesuai dengan tahap usia anak. Dalam mengembangkan kemampuan berhitung anak dilakukan di Taman Kanak-kanak PGRI kerinci ini sangat bervariasi, anak lebih banyak melakukan kegiatan baik itu berupa melalui permainan yang dirancang oleh guru dengan menggunakan media yang menarik. Tidak hanya terpaku pada menulis dan mengerjakan lembaran kerja anak dalam menanamkan konsep berhitung. Anak banyak melakukan percobaan seperti anak terlibat langsung dalam suatu permainan dalam menyelesaikan suatu kegiatan dengan memperlihatkan bentuk benda nya langsung kepada anak sehingga anak dapat membedakan, menghitung jumlah gambar buah, dan mencocokkan angka dengan jumlah gambar pada kepingan buah. 


\section{UCAPAN TERIMAKASIH}

Terimakasih kepada kepala sekolah Taman Kanak-kanak PGRI Kerinci yang sudah memberikan izin kepada penulis untuk melakukan penelitian di TK tersebut dan kepada editor, reviwer dan pengelola Jurnal Obsesi yang telah memberi masukan serta telah memperbaiki artikel ini menjadi lebih baik.

\section{DAFTAR PUSTAKA}

Amaris, D. U., Rakimahwati, \& Marlina, S. (2018). Pengaruh Media Busy Book Terhadap Kemampuan Berhitung Anak Usia Dini Di Taman Kanak-Kanak Fadhilah Amal 3 Padang. Jurnal Usia Dini, 4(2), 8-17. https:// doi.org/10.31004/obsesi.v2i1.13

Aprinawati, I. (2017). Penggunaan Media Gambar Seri Untuk Meningkatkan Kemampuan Berbicara Anak Usia Dini. Jurnal Obsesi : Jurnal Pendidikan Anak Usia Dini, 1(1), 12-18. https://doi.org/10.31004/obsesi.v1i1.33

Dewi, A. C., Hapidin, \& Akbar, Z. (2019). Pengaruh Model Pembelajaran dan Kemampuan Berpikir Kritis terhadap Pemahaman Sains Fisik. Jurnal Obsesi : Jurnal Pendidikan Anak Usia Dini, 3(1), 18-29. https:// doi.org/10.31004/obsesi.v3i1.136

Fakhruddin, A. U. (2010). Sukses Menjadi Guru TK-PAUD. Jogjakarta:Bening.

Farihah, H. (2017). Mengembangkan Kemampuan Berhitung Anak Usia Dini Melalui Kegiatan Bermain Stick Angka. Jurnal Teladan, 2(1), 2-20. https://doi.org/10.29313/ga.v1i2.3316

Hasiana, I., \& Wirastania, A. (2017). Pengaruh Musik dalam Mengembangkan Kemampuan Mengenal Bilangan Siswa Kelompok A di TK Lintang Surabaya. Jurnal Obsesi : Jurnal Pendidikan Anak Usia Dini, 1(2), 131-138. https:/ / doi.org/10.31004/ obsesi.v1i2.23

Inten, D. N., \& Permatasari, A. N. (2019). Literasi Kesehatan pada Anak Usia Dini melalui Kegiatan Eating Clean. Jurnal Obsesi : Jurnal Pendidikan Anak Usia Dini, 3(2), 366-376. https://doi.org/10.31004/obsesi.v3i2.188

Ismayani, A. (2010). Fun Math With Children. PT Elex Media: Jakarta.

Isnaningsih, A., \& Rohman, A. (2019). Participation of Mothers Who Work in Religious Activities Towards Child Behavior. Jurnal Obsesi : Jurnal Pendidikan Anak Usia Dini, 3(1), 199. https://doi.org/10.31004/obsesi.v3i1.157

Malapata, E., \& Wijayanigsih, L. (2019). Meningkatkan Kemampuan Berhitung Anak Usia 45 Tahun melalui Media Lumbung Hitung. Jurnal Obsesi : Jurnal Pendidikan Anak Usia Dini, 3(1), 283-293. https:/ / doi.org/10.31004/obsesi.v3i1.183

Mirawati. (2017). Matematika Kreatif: Pembelajaran Matematika bagi Anak Usia Dini Melalui Kegiatan yang Menyenangkan dan Bermakna. Pedagogi: Jurnal Anak Usia Dini dan Pendidikan Anak Usia Dini, 3(3a), 1-8.

Mursid. (2015). Pengembangan Pembelajaran PAUD. Bandung:PT Remaja Rosdakarya.

Perdina, S., Safrina, R., \& Sumadi, T. (2019). Peningkatan Kemampuan Sosial melalui Bermain Kartu Estafet pada Anak Usia Dini. Jurnal Obsesi : Jurnal Pendidikan Anak Usia Dini, 3(2), 440. https:// doi.org/10.31004/obsesi.v3i2.222

Pradana, P. H. (2016). Pengaruh Permainan Balok Angka Terhadap Kemampuan Mengenal Lambang Bilangan Pada Anak Usia Dini. Jurnal paud tambusai, 2(2), 18-25.

Reswita, \& Wahyuni, S. (2018). Efektivitas Media Pasir dalam Meningkatkan Kemampuan Konsep Bilangan pada Anak Usia 5-6 Tahun di Tk Aisyiyah Bengkalis. Lectura: Jurnal Pendidikan, 9(1), 43-51. https:// doi.org/10.31849/lectura.v9i1.927

Smith, S. S. (2009). Early Childhood Mathematics. Pearson: America.

Sujiono, Y. N. (2009). Pengembangan Pembelajaran PAUD. PT Indek: Jakarta, 6(1), 56-67.

Suprapti, E. (2016). Peningkatan Pembelajaran Matetika Anak Usia Dini dengan Microsoft Powerpoint Ispring pada Materi Pengenalan Konsep Bilangan. Jurnal Pedagogi, 2(1), 27-33. 
Suryana, D. (2013). Pendidikan Anak Usia Dini. Padang. Padang:UNP Press.

Undang-undang Sistem Pendidikan Nasional Nomor 20 Tahun $2003 . \quad$ (n.d.). https:// doi.org/10.16309/j.cnki.issn.1007-1776.2003.03.004

Waspodo, M. (2012). Pengembangan Profesional Berkelanjutan bagi Guru PAUD. Jurnal Ilmiah VISI P2TK PAUD NI, 7(1), 77-81.

Yanti, S. D., Turdjai, \& Kurniah, N. (2017). Penerapan Metode Bermain Sensorimotor untuk Meningkatkan Kognitif dan Motorik Halus Anak (Studi Pada Anak Kelompok A1 PAUD Negeri Pembina 1 Kota Bengkulu). Jurnal Ilmiah Teknologi Pendidikan, 7(2), 7177. 